\title{
Bone morphogenetic protein 4 inhibits insulin secretion from rodent beta cells through regulation of calbindin 1 expression and reduced voltage-dependent calcium currents
}

\author{
Gitte L. Christensen ${ }^{1}$ • Maria L. B. Jacobsen ${ }^{1}$. Anna Wendt ${ }^{2}$ - Ines G. Mollet ${ }^{2}$ • \\ Josefine Friberg $^{1} \cdot$ Klaus S. Frederiksen ${ }^{3} \cdot$ Michael Meyer $^{4} \cdot$ Christine Bruun $^{5}$. \\ Lena Eliasson ${ }^{2} \cdot$ Nils Billestrup ${ }^{1}$
}

Received: 20 November 2014 / Accepted: 4 March 2015 /Published online: 2 April 2015

(C) Springer-Verlag Berlin Heidelberg 2015

\begin{abstract}
Aims/hypothesis Type 2 diabetes is characterised by progressive loss of pancreatic beta cell mass and function. Therefore, it is of therapeutic interest to identify factors with the potential to improve beta cell proliferation and insulin secretion. Bone morphogenetic protein 4 (BMP4) expression is increased in diabetic animals and BMP4 reduces glucose-stimulated insulin secretion (GSIS). Here, we investigate the molecular mechanism behind this inhibition.

Methods BMP4-mediated inhibition of GSIS was investigated in detail using single cell electrophysiological measurements and live cell $\mathrm{Ca}^{2+}$ imaging. BMP4-mediated gene expression changes were investigated by microarray profiling, quantitative PCR and western blotting.
\end{abstract}

Electronic supplementary material The online version of this article (doi:10.1007/s00125-015-3568-x) contains peer-reviewed but unedited supplementary material, which is available to authorised users.

Lena Eliasson

Lena.Eliasson@med.lu.se

Nils Billestrup

Billestrup@sund.ku.dk

1 Department of Biomedical Sciences, University of Copenhagen, Nørre Alle 20, 2100 Copenhagen, Denmark

2 Lund University Diabetes Center, Lund University, CRC 91-11, Jan Waldenströms gata 35 SUS Malmö, 20502 Malmö, Sweden

3 Biopharmaceuticals Research Unit, Novo Nordisk A/S, Måløv, Denmark

4 Department of Cellular Physiology, Ludwig Maximilian University of Munich, Munich, Germany

5 Department of Incretin and Islet Biology, Novo Nordisk A/S, Måløv, Denmark
Results Prolonged exposure to BMP4 reduced GSIS from rodent pancreatic islets. This inhibition was associated with decreased exocytosis due to a reduced $\mathrm{Ca}^{2+}$ current through voltage-dependent $\mathrm{Ca}^{2+}$ channels. To identify proteins involved in the inhibition of GSIS, we investigated global gene expression changes induced by BMP4 in neonatal rat pancreatic islets. Expression of the $\mathrm{Ca}^{2+}$-binding protein calbindin 1 was significantly induced by BMP4. Overexpression of calbindin1 in primary islet cells reduced GSIS, and the effect of BMP4 on GSIS was lost in islets from calbindin1 (Calb1) knockout mice.

Conclusions/interpretation We found BMP4 treatment to markedly inhibit GSIS from rodent pancreatic islets in a calbindin1-dependent manner. Calbindin1 is suggested to mediate the effect of BMP4 by buffering $\mathrm{Ca}^{2+}$ and decreasing $\mathrm{Ca}^{2+}$ channel activity, resulting in diminished insulin exocytosis. Both BMP4 and calbindin1 are potential pharmacological targets for the treatment of beta cell dysfunction.

Keywords Beta cells · BMP4 - Calb1 · Calbindin1 · Diabetes $\cdot$ Exocytosis $\cdot$ Insulin secretion
Abbreviations
BMP Bone morphogenetic protein
ECM Extracellular matrix
FDR False discovery rate
GSIS Glucose-stimulated insulin secretion
HBSS Hanks' balanced salt solution
KO Knockout
VDCC Voltage-dependent $\mathrm{Ca}^{2+}$ channel
WT Wild type 


\section{Introduction}

Pancreatic beta cells initially compensate for insulin resistance by increasing their mass and activity to maintain normal blood glucose levels [1]. In individuals who progress to develop type 2 diabetes, beta cells eventually fail to adapt and progressive loss of functional beta cells starts [1]. Although current type 2 diabetes drugs targeting insulin resistance or insulin secretion are initially efficient, beta cell mass and function tend to decline over time $[2,3]$. Unidentified factors may limit the ability of the beta cells to adapt to insulin resistance. In our search for factors with inhibitory effects on beta cells, we recently described the inhibition of beta cell proliferation and insulin secretion by bone morphogenetic protein 4 (BMP4) [4].

BMPs belong to the TGF- $\beta$ protein family, members of which are known to play central roles in pancreas and islet development [5-10]. While the role of BMPs in the developing pancreas and beta cells has gained much attention [8, 11, 12], less is known about their function in the postnatal pancreas. There is increasing evidence that BMP $2 / 4$ are inflammatory markers in various tissues under diabetic conditions [13-15]. We recently showed that BMP $2 / 4$ are expressed in pancreatic islets and upregulated during diabetes progression in islets from $d b / d b$ mice and by proinflammatory cytokines in vitro [4]. Although the culture of pancreatic islets in the presence BMP2/4 negatively affects beta cell function, it appears that the effect of BMPs in vivo is more complex. Beta cell specific deletion of BMP receptor 1A (Bmprla) resulted in impaired glucose-stimulated insulin secretion (GSIS), whereas BMP4 transgene overexpression increased GSIS [16]. In contrast, deficiency of inhibitor of differentiation 1 (Id1), encoding a central BMP-regulated transcription factor, resulted in enhanced insulin secretion and protection from diet-induced glucose intolerance, suggesting that BMPs and ID1 normally inhibit adult beta cell function [17]. BMPs are both released from and affect several metabolically relevant tissues, including fat, liver and kidney, thus adding to the complexity of the role of BMPs in metabolism $[14,18,19]$. To characterise the direct effects of BMPs on beta cells, we recently reported BMP4mediated inhibition of beta cell proliferation and repression of GSIS from mouse, rat and human islets [4]. Here, we further characterise the effects of BMP4 on insulin secretion using single cell electrophysiological measurements, and evaluate gene regulation to identify the molecular mechanism for the observed inhibition of insulin secretion.

\section{Methods}

\section{Rat islet isolation and culture}

Neonatal rat islets of Langerhans were isolated from 4-day-old Wistar rat pups (Taconic, Lille Skensved, Denmark), as previously described [20]. All mice were housed according to the Principles of Laboratory Care. The isolated islets were pre-cultured for 7-10 days in RPMI 1640 with UltraGlutamine (Lonza, Vallensbaek, Denmark) and supplemented with $10 \%$ newborn calf serum (Biological Industries, Kibbutz Beit Haemek, Israel), $100 \mathrm{U} / \mathrm{ml}$ penicillin and $100 \mu \mathrm{g} / \mathrm{ml}$ streptomycin (Gibco, Life Technologies, Taastrup, Denmark) in $5 \% \mathrm{CO}_{2}$ at $37^{\circ} \mathrm{C}$. For experiments, rat islets were cultured as intact and free-floating in medium supplemented with $2 \%$ human serum (BioWhittaker, Lonza) or as single cells following digestion with $0.2 \%$ trypsin (Gibco) and $10 \mathrm{mmol} / \mathrm{l}$ EDTA (Gibco) in Hanks' balanced salt solution (HBSS). Dispersed islets were cultured on coverslips coated with bovine corneal extracellular matrix (ECM; Biological Industries) in the medium described above containing $2 \%$ human serum.

\section{Mouse islet isolation and culture}

Pancreatic islets from 10-12-week-old female NMRI mice were isolated by collagenase digestion, as previously described [21]. Islets were handpicked into albumin-coated Petri dishes (1 mg albumin/ml HBSS) and cultured for 1 day in medium I (RPMI 1640 containing $10 \mathrm{mmol} / \mathrm{l}$ glucose and $10 \% \mathrm{FCS}, 100 \mathrm{U} / \mathrm{ml}$ penicillin, and $100 \mu \mathrm{g} / \mathrm{ml}$ streptomycin) and then for a further 3 days in medium II (RPMI 1640 containing $10 \mathrm{mmol} / \mathrm{l}$ glucose and $2 \% \mathrm{FCS}, 100 \mathrm{U} / \mathrm{ml}$ penicillin, and $100 \mu \mathrm{g} / \mathrm{ml}$ streptomycin) in the absence or presence of BMP4 $(50 \mathrm{ng} / \mathrm{ml})$. After culture, mouse islets were fixed for transmission electron microscopy (see electronic supplementary material (ESM) Fig. 1 for further details) or dispersed into single cells using $\mathrm{Ca}^{2+}$-free buffer for electrophysiological experiments.

Pancreatic islets from 12-19-week-old 129SV/C57/6crl wild type (WT) and calbindin 1 (Calbl) knockout (KO) mice (calbindin $^{\mathrm{D} 28 \mathrm{k}^{-1}}$ ) [22] were isolated by bile duct perfusion of the pancreas with Liberase (Roche, Hvidovre, Denmark). Digestion was stopped by the addition of HBSS buffer containing $\mathrm{Mg}^{2+}$ and $\mathrm{Ca}^{2+}$ (Gibco), $3 \mathrm{~g} / 1 \mathrm{BSA}$ and $0.5 \mathrm{~g} / 1$ D-glucose. Islets were filtered through a $400 \mu \mathrm{m}$ mesh, followed by $100 \mu \mathrm{m}$ and $70 \mu \mathrm{m}$ mesh strainers (BD Falcon, Albertslund, Denmark). Retained islets were handpicked under a dissection microscope and cultured for 1 day in medium I. The following day, islets were transferred to medium II, in which they were kept throughout stimulation. Female mice were used for electrophysiological experiments and male mice for insulin secretion assays.

\section{Microarray analysis}

A total of 800 intact, free-floating rat islets were cultured in $5.5 \mathrm{~cm}$ Petri dishes for 5-10 days and then exposed to BMP4 for $96 \mathrm{~h}$. Total RNA was extracted using TRIzol (Gibco). One 
microgram of total RNA was labelled using a One-Cycle Target labelling kit (Affymetrix, Santa Clara, CA, USA) following the manufacturer's instructions. Hybridisation cocktails were hybridised to Rat Genome 2302.0 GeneChip arrays (Affymetrix) at $45^{\circ} \mathrm{C}$ for $17 \mathrm{~h}$ (at $60 \mathrm{rpm}$ ) in a Hybridization Oven 640 (Affymetrix). GeneChips were then washed and stained in a GeneChip fluidics station 450 using the EukGEWS2v5_450 fluidics protocol (Affymetrix), and then scanned in a GeneChip scanner 3000 (Affymetrix). Microarray data were normalised and gene expression measures derived using the RMA algorithm and the 'Affy' Bioconductor package (www.bioconductor.org). A Custom chip definition file obtained from brainarray.mbni.med.umich.edu was used. Qlucore Omics Explorer 3.0 (Qlucore, Lund, Sweden) was used for statistical analysis of the normalised data. For comparing BMP4 to vehicle treatment, microarray data were variance filtered $(\sigma / \sigma(\max )>0.1)$, and the two groups compared using the Student's $t$ test (false discovery rate $[\mathrm{FDR}]=5 \%$; Benjamini Hochberg correction for multiple testing).

\section{Analysis of Calb1 and Ins1 mRNA expression by real-time quantitative PCR}

A total of 800 intact neonatal rat islets cultured for 5 days were exposed to $50 \mathrm{ng} / \mathrm{ml} \mathrm{BMP} 4$ for the indicated time periods, and then total RNA was extracted using TRIzol. cDNA synthesis was performed using TaqMan Reverse Transcription Reagents (Applied Biosystems, Carlsbad, CA, USA). TaqMan Gene Expression probes against rat Calb1 (Rn00583140_m1), Ins 1 (Rn02121433_g1) and Ppia (Rn_00690933_m1) were obtained from Applied Biosystems. Samples were run on an ABI PRISM 7900HT Sequence Detection System (Applied Biosystems). Each sample was run in duplicate or triplicate and expression was normalised to the internal control, Ppia.

\section{Analysis of calbindin1 protein expression by western blotting}

A total of 1,000 intact neonatal rat islets were cultured for 510 days prior to exposure to $50 \mathrm{ng} / \mathrm{ml} \mathrm{BMP} 4$ for $24,48,72$ or $96 \mathrm{~h}$. SDS-PAGE and western blotting were performed as described previously [23]. Primary antibodies were rabbit anti-calbindin1 (Cell Signaling Technology, AH Diagnostics, Aarhus, DK) and mouse anti- $\beta$-actin (Abcam, Cambridge, UK). Chemiluminescence was detected using Lumi-GLO (Cell Signaling Technology) and visualised using Las 3000 (Fujifilm, GE Healthcare Europe, Brondby, Denmark). Densitometric scanning was performed using ImageJ freeware (National Institutes of Health, Bethesda, MD, USA).

\section{GSIS}

On day 7-10 after isolation, 40 neonatal rat islets were transferred to medium containing $2 \%$ human serum, $100 \mathrm{U} / \mathrm{ml}$ penicillin and $100 \mu \mathrm{g} / \mathrm{ml}$ streptomycin, and then stimulated with $50 \mathrm{ng} / \mathrm{ml}$ BMP4 for 0-96 h. Mouse islets were stimulated the day after isolation. For each condition, 20 islets were transferred to Krebs-Ringer HEPES buffer (KRHB; $115 \mathrm{mmol} / \mathrm{l}$ $\mathrm{NaCl}, 4.7 \mathrm{mmol} / \mathrm{l} \mathrm{KCl}, 2.6 \mathrm{mmol} / \mathrm{C} \mathrm{CaCl}_{2}, 1.2 \mathrm{mmol} / \mathrm{l}$ $\mathrm{KH}_{2} \mathrm{PO}_{4}, 1.2 \mathrm{mmol} / 1 \mathrm{MgSO}_{4}, 10 \mathrm{mmol} / \mathrm{l}$ HEPES, $0.2 \%$ BSA, $2 \mathrm{mmol} / \mathrm{l}$ glutamine, $5 \mathrm{mmol} / 1 \mathrm{NaHCO}_{3}$ and $1 \%$ each penicillin and streptomycin, $\mathrm{pH}$ 7.4) containing $2 \mathrm{mmol} / \mathrm{l}$ glucose and incubated for 90 min prior to the GSIS experiment. Islets were sequentially exposed to $2 \mathrm{mmol} / \mathrm{l}$ glucose, $20 \mathrm{mmol} / \mathrm{l}$ glucose, and $20 \mathrm{mmol} / \mathrm{l}$ glucose plus $10 \mu \mathrm{mol} / 1$ forskolin (Sigma-Aldrich, Brondby, Denmark) for $30 \mathrm{~min}$. The buffer was then collected from each experimental group and insulin content was determined using an in-house insulin ELISA. Results were corrected for DNA content using QuantIT PicoGreen dsDNA Reagent and Kit (Invitrogen, Life Technologies, Taastrup, Denmark).

\section{Production of Calb1 lentivirus}

Mouse Calb1 cDNA in the pENTR221 entry vector (Invitrogen) was transferred to the pLenti6.2/v5DEST Gateway vector (Invitrogen). Lentivirus was produced in HEK293ft cells using the ViraPower Lentiviral Expression System (Invitrogen, Carlsbad, CA, USA) and lentivirus particles were harvested by ultracentrifugation. Viral titer was determined in HT1080 cells (Invitrogen). The virus was used at a multiplicity of infection of 5 for $6 \mathrm{~h}$.

\section{Insulin release in single cells overexpressing calbindin1}

Dispersed rat islet cells were cultured on coverslips coated with bovine corneal ECM in 4-well plates for 4 days prior to transduction with Calb1- or GFP-expressing lentivirus for $6 \mathrm{~h}$ at a MOI of 5 . After $96 \mathrm{~h}$, GSIS was evaluated as described above.

\section{Electrophysiology}

Capacitance measurements and ion current measurements were performed on single beta cells in a mixture of dispersed islets cells using the patch-clamp technique, as previously described [21]. Beta cells where identified by their size and the inactivation properties of the voltage-dependent $\mathrm{Na}^{+}$channel $[24,25]$. Exocytosis was evoked by a train of $10500 \mathrm{~ms}$ depolarisation events from $-70 \mathrm{mV}$ to $0 \mathrm{mV}$ at a frequency of $1 \mathrm{~Hz}$ and measured as changes in membrane capacitance. The voltage-dependent $\mathrm{Ca}^{2+}$ channel (VDCC) current to voltage relationship was determined using a protocol in which the 
membrane was depolarised from $-70 \mathrm{mV}$ to voltages between $-40 \mathrm{mV}$ and $+40 \mathrm{mV}$ for $50 \mathrm{~ms}$.

\section{Live cell $\mathrm{Ca}^{+}$imaging}

Islets were loaded with $4 \mu \mathrm{mol} / \mathrm{l}$ Fura-2-acetoxymethyl ester (TefLabs, Austin, TX, USA) for $40 \mathrm{~min}$, followed by $30 \mathrm{~min}$ de-esterification in imaging buffer at $\mathrm{pH} 7.4(3.6 \mathrm{mmol} / \mathrm{K} \mathrm{KCl}$, $0.5 \mathrm{mmol} / 1 \mathrm{MgSO}_{4}, 2.5 \mathrm{mmol} / 1 \mathrm{CaCl}_{2}, 140 \mathrm{mmol} / \mathrm{l} \mathrm{NaCl}$, $2 \mathrm{mmol} / \mathrm{l} \mathrm{NaHCO} 3,0.5 \mathrm{mmol} / 1 \mathrm{NaH}_{2} \mathrm{PO}_{3}$ and $5 \mathrm{mmol} / \mathrm{l}$ HEPES). High $\mathrm{K}^{+}$buffer was identical except for $70 \mathrm{mmol} / \mathrm{l}$ $\mathrm{NaCl}$ and $70 \mathrm{mmol} / \mathrm{l} \mathrm{KCl}$. Imaging was performed using a Polychrome V monochromator (TILL Photonics, Graefeling, Germany) and an Eclipse Ti Microscope (Nikon, Tokyo, Japan) with a ER-BOB-100 trigger on an iXON3 camera and iQ2 (Andor Technology, Belfast, UK) software. Recording was performed at 1 frame $/ \mathrm{s}$ at $37^{\circ} \mathrm{C}$ under perfusion at $1 \mathrm{ml} / \mathrm{min}$. A region was marked around each islet and the light intensity was recoded in that region to obtain the integrated light intensity per unit area (in $\left.\mu \mathrm{m}^{2}\right)$ at $340 \mathrm{~nm}(150 \mathrm{~ms}$ exposure) and $380 \mathrm{~nm}$ (100 ms exposure). These measured intensities were then used to calculate the ratio of Fura- 2 bound $(340 \mathrm{~nm})$ and unbound $(380 \mathrm{~nm})$ to $\mathrm{Ca}^{2+}$ at 1 frame/s.

\section{Results}

\section{BMP4 inhibits GSIS}

The effect of BMP4 on GSIS was investigated in neonatal rat islets. Pretreatment with $50 \mathrm{ng} / \mathrm{ml} \mathrm{BMP4}$ for 0-4 days resulted in a reduction in GSIS after $48 \mathrm{~h}$ (Fig. 1a). Acute stimulation with BMP4 $(0 \mathrm{~h})$ or pre-stimulation for up to $24 \mathrm{~h}$ had no effect on insulin secretion. In addition, doses as low as $2 \mathrm{ng} / \mathrm{ml}$ inhibit insulin secretion [4]. BMP4 stimulation had no effect on total islet insulin content (Fig. 1b) or Ins 1 mRNA levels (Fig. 1c). We did not observe any effect on the number, size or membrane proximity of insulin granules using high-resolution electron microscopy of adult mouse islets (ESM Fig. 1).

\section{BMP4 inhibits exocytosis and VDCC current}

The fact that BMP4 inhibits GSIS without affecting the total insulin content or total number of insulin granules suggests that BMP4 may target the secretory machinery. For a further detailed electrophysiological analysis of insulin secretion, we used dispersed primary mouse islet cells. We investigated exocytosis measured as increased membrane capacitance and found a reduced depolarisation-evoked increase in membrane capacitance in BMP4-treated primary mouse beta cells (Fig. 2a-e). The most pronounced effect was observed during depolarisation events 2-10 ('Depol 2-10'; Fig. 2d). This was
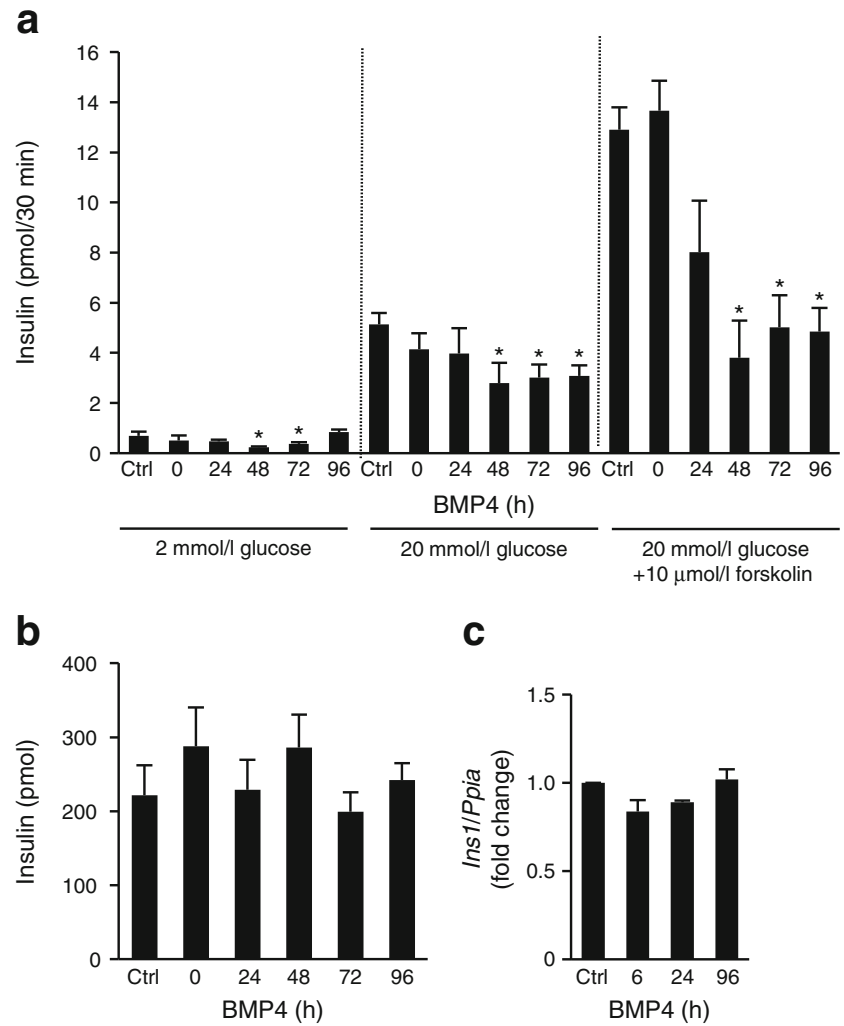

C

Fig. 1 BMP4 inhibits GSIS without affecting total insulin content. (a) Neonatal rat islets were pre-exposed to $50 \mathrm{ng} / \mathrm{ml} \mathrm{BMP4}$ for $0-96 \mathrm{~h}$ and GSIS was performed as described. (b) Post-assay insulin content of islets. DNA content was used for normalisation in (a) and (b). (c) A total of 800 intact neonatal rat islets were exposed to $50 \mathrm{ng} / \mathrm{ml}$ BMP4 for 0-96 h. Relative Ins 1 mRNA expression was normalised to Ppia expression. Data are mean \pm SEM. Statistical significance was evaluated using ANOVA followed by Dunnett's $t$ test. ${ }^{*} p<0.05$

confirmed by a continued reduction in the exocytotic response to a second train of depolarisation events performed $2 \mathrm{~min}$ later (Fig. 2e). Exocytosis is highly dependent on $\mathrm{Ca}^{2+}$ influx through VDCCs [26]. We therefore determined the VDCC influx to voltage relationship (Fig. 2f, g). Beta cells exposed to BMP4 show $\sim 50 \%$ reduced $\mathrm{Ca}^{2+}$ influx at $0 \mathrm{mV}$. BMP4 increased the $\mathrm{Ca}^{2+}$ sensitivity, i.e. increased the membrane capacitance per $\mathrm{Ca}^{2+}$ charge unit entering the cell, which suggests that the BMP4-dependent decrease in exocytosis is caused by a reduced $\mathrm{Ca}^{2+}$ current rather than a direct effect on exocytosis (Fig. 2h). Moreover, BMP4 may have a direct stimulatory effect on exocytosis that is less pronounced than the effect on the $\mathrm{Ca}^{2+}$ current.

To gain further insight into the mechanism of BMP4 inhibition of exocytosis, we performed live cell $\mathrm{Ca}^{2+}$ imaging of primary adult mouse islets. Evaluation of $\mathrm{Ca}^{2+}$ fluctuations was determined by differences in the Fura-2 340 nm:380 nm ratio (representative traces shown in Fig. 2i, j; all traces are shown in ESM Fig. 2). Temporal fluctuation of the intracellular $\mathrm{Ca}^{2+}$ in response to glucose were organised into two classes: class 1 islets have separate first and second phases, in 


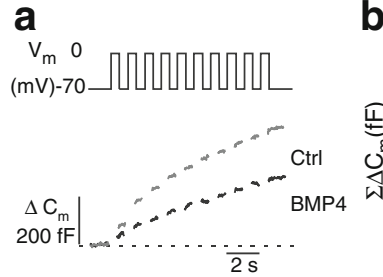

f

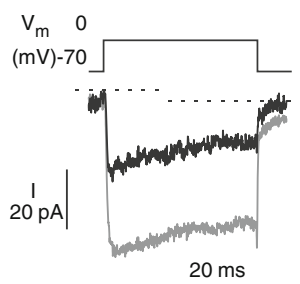

i

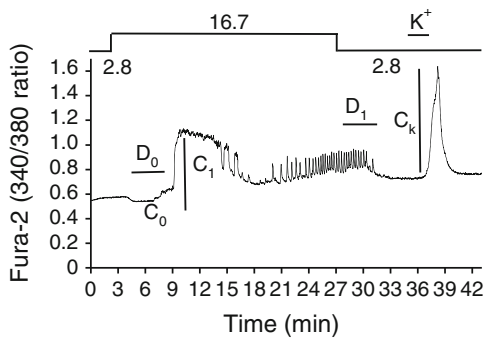

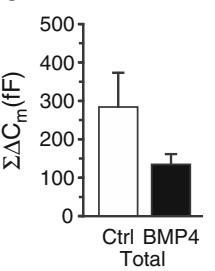

g
C

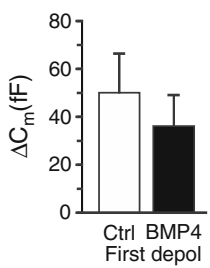

d

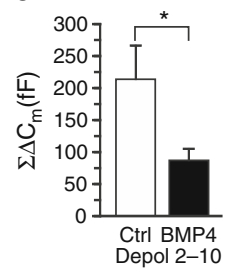

e

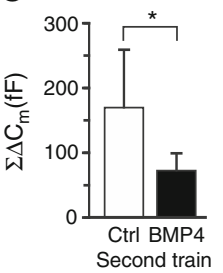

h

$\mathrm{V}_{\mathrm{m}}(\mathrm{mV})$
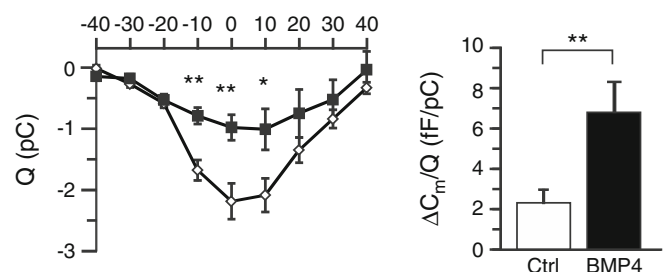

j

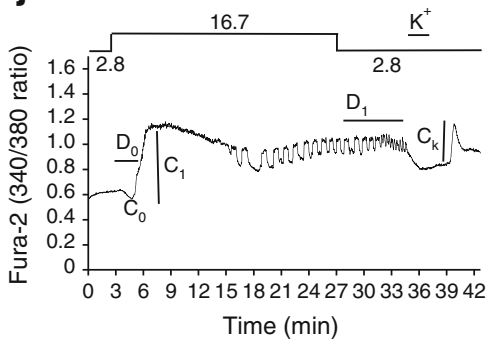

I
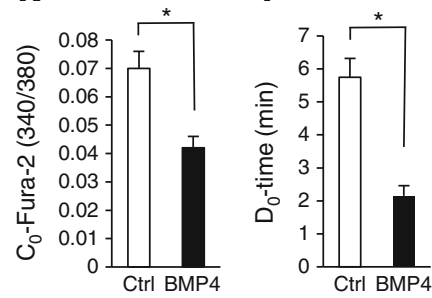

m

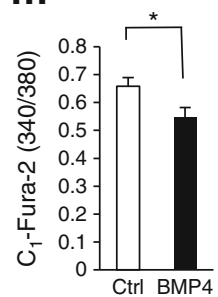

n

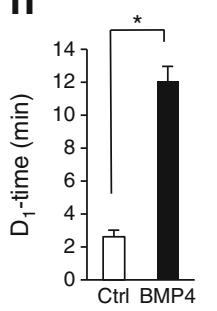

o

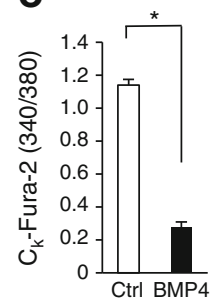

Fig. 2 BMP4 diminishes membrane capacitance increase and $\mathrm{Ca}^{2+}$ influx through VDCCs. (a) Example trace of depolarisation-induced exocytosis, measured as changes in cell membrane capacitance $\left(\Delta \mathrm{C}_{\mathrm{m}}\right)$ in a single mouse beta cell. (b) The mean increase in membrane capacitance evoked by a train of 10 depolarisation events, (c) the first depolarisation and (d) depolarisations 2-10. (e) Mean capacitance increase evoked by a second train applied 2 min later. (f) Example trace from a VDCC in a beta cell incubated in the absence (grey) and presence (black) of BMP4. (g) The measured charge $(\mathrm{Q})$ as a function of the membrane voltage $\left(\mathrm{V}_{\mathrm{m}}\right)$ during a $50 \mathrm{~ms}$ depolarisation. White diamonds, control cells; black squares, BMP4-treated cells. (h) The $\mathrm{Ca}^{2+}$ sensitivity of the exocytotic response measured as the capacitance increase during the first depolarisation event of the train $\left(\Delta \mathrm{C}_{\mathrm{m}}\right)$ shown in (c) divided by the
$\mathrm{Ca}^{2+}$ influx (charge $=\mathrm{Q}$ ) during the same $500 \mathrm{~ms}$ depolarisation. Data in (b-e) and (g-h) are mean \pm SEM of $n=9-16$ experiments in each group. ${ }^{*} p<0.05,{ }^{*} p<0.01$. (i, j) Representative examples of a $\mathrm{Ca}^{2+}$ trace obtained from one islet pre-treated for 3 days with (i) vehicle (control) or (j) BMP4. $\mathrm{C}_{0}, \mathrm{Ca}^{2+}$ dip occurring when $16.7 \mathrm{mmol} / \mathrm{l}$ glucose reaches the islets; $\mathrm{D}_{0}$, time delay between $16.7 \mathrm{mmol} / \mathrm{l}$ glucose exposure and the first $\mathrm{Ca}^{2+}$ peak; $\mathrm{C}_{1}$, amplitude of the first phase peak; $\mathrm{D}_{1}$, time delay in response to low glucose; $\mathrm{C}_{\mathrm{k}}$, amplitude of high potassium peak. The staircase indicates the glucose concentrations of $2.8 \mathrm{mmol} / 1 \mathrm{l}(2.8)$ and $16.7 \mathrm{mmol} / 1$ (16.7). The line with $\mathrm{K}^{+}$indicates the addition of $70 \mathrm{mmol} /$ $1 \mathrm{KCl}$. Summary statistics of $\mathrm{Ca}^{2+}$ imaging traces shown for $(\mathbf{k}) \mathrm{C}_{0}$, (l) $\mathrm{D}_{0}$, (m) $\mathrm{C}_{1}$, (n) $\mathrm{D}_{1}$ and (o) $\mathrm{C}_{\mathrm{k}}$. Ctrl, control; Depol, depolarisation which a defined first phase peak is followed by a lowering of $\mathrm{Ca}^{2+}$ and a second phase with distinct regularly spaced $\mathrm{Ca}^{2+}$ oscillations; class 2 islets exhibit a rise in $\mathrm{Ca}^{2+}$ with no clear first and second phases and no distinct oscillations in the second phase. In all, $64 \%$ of control islets and $26 \%$ of BMP4treated islets had a distinct first peak and second phase oscillations in the presence of high glucose (see ESM Table 1). In addition, there was a significant reduction in the first lowering of $\mathrm{Ca}^{2+}$ (Fig. 2j, k) and the first phase peak amplitude at $16.7 \mathrm{mmol} / \mathrm{l}$ glucose (Fig. 2j, m) and in the response to depolarising $\mathrm{K}^{+}$(Fig. 2j, o). The response time after increased glucose concentration was reduced by BMP4 treatment (Fig. 2j, 1), whereas the response time to glucose lowering was increased 
(Fig. 2n). We did not observe significant changes in the amplitude or frequency of $\mathrm{Ca}^{2+}$ oscillations.

\section{BMP4 mediates upregulation of calbindin1}

Since the effects of BMP4 on GSIS were first observed after $48 \mathrm{~h}$ exposure, we hypothesised that gene regulation is required for this effect. To unravel the mechanism of BMP4-mediated inhibition of GSIS we therefore performed a gene expression array comparing three independent sets of vehicle- and BMP4-treated neonatal rat islets $(96 \mathrm{~h})$. Using a FDR of 5\%, we found 102 genes to be regulated by BMP4 (ESM Table 2). Genes up- or downregulated by more than twofold are shown in Table 1. Regulation of seven of these genes was verified in independent rat islet samples by q-pcr (denoted by ${ }^{\mathrm{a}}$ in Table 1 ).

We paid particular attention to genes known to be involved in hormone secretion and $\mathrm{Ca}^{2+}$ handling, based on the effects of BMP4 on insulin secretion, exocytosis and $\mathrm{Ca}^{2+}$ channel activity. We observed no regulation of BMP receptors or L-type $\mathrm{Ca}^{2+}$ channel subunits. One of the most strongly regulated genes was Calb1, which encodes an EF-hand $\mathrm{Ca}^{2+}$-binding protein previously shown to regulate $\mathrm{Ca}^{2+}$ currents through VDCC and inhibit GSIS in beta cells [27-29]. BMP4 increased the expression of Calb1 mRNA by sixfold in neonatal rat islets, resulting in a 2.5 -fold increase in calbindin 1 protein after $96 \mathrm{~h}$ (Fig. 3a,b) As shown in primary neonatal rat islets, BMP4 increased the expression of Calb1 mRNA in adult mouse islets (Fig. 3c).
Table 1 Genes regulated by at least twofold in neonatal rat islets exposed to $50 \mathrm{ng} / \mathrm{ml} \mathrm{BMP4}$ for $96 \mathrm{~h}$

\begin{tabular}{|c|c|c|}
\hline Gene & Protein name & Fold change \\
\hline$I d 3$ & DNA-binding protein inhibitor ID-3 & $17.92^{\mathrm{a}}$ \\
\hline Id 1 & DNA-binding protein inhibitor ID-1 & $16.52^{\mathrm{a}}$ \\
\hline Lypd8 & Ly6/PLAUR domain containing protein 8 precursor & 9.66 \\
\hline $\operatorname{Irx}-3$ & Iroquois-class homeodomain protein IRX-3 & 5.40 \\
\hline Calb1 & Calbindin 1 & $4.62^{\mathrm{a}}$ \\
\hline $\operatorname{Id} 2$ & DNA-binding protein inhibitor ID-2 & $4.25^{\mathrm{a}}$ \\
\hline Micalcl & MICAL C-terminal-like protein & 4.06 \\
\hline Fam101a & Family with sequence similarity 101. member A (Fam101a) & 3.85 \\
\hline Lgals4 & Galectin-4 & 3.72 \\
\hline Bambi & BMP and activin membrane-bound inhibitor homologue & $3.25^{\mathrm{a}}$ \\
\hline Atoh8 & Protein atonal homologue 8 & 3.13 \\
\hline $\operatorname{Arc}$ & Activity-regulated cytoskeleton-associated protein & 3.08 \\
\hline Mlph & Melanophilin & 2.90 \\
\hline Camklg & Calcium/calmodulin-dependent protein kinase type $1 \mathrm{G}$ & 2.82 \\
\hline Chst10 & Carbohydrate sulfotransferase 10 & 2.81 \\
\hline Dlkl & Protein delta homologue 1 & 2.75 \\
\hline Tppp3 & Tubulin polymerisation-promoting protein family member 3 & 2.72 \\
\hline Tmem 100 & Transmembrane protein 100 & 2.68 \\
\hline$C k b$ & Creatine kinase B-type & 2.63 \\
\hline Ppp1r36 & Protein phosphatase 1 regulatory subunit 36 & 2.59 \\
\hline Tmem100 & Transmembrane protein 100 & 2.51 \\
\hline Rtn $4 r l 1$ & Reticulon-4 receptor-like 1 & 2.44 \\
\hline St5 & Suppression of tumorigenicity 5 protein & 2.34 \\
\hline Akap12 & A-kinase anchor protein 12 & 2.30 \\
\hline Vash2 & Vasohibin-2 & 2.20 \\
\hline$D d x 31$ & Probable ATP-dependent RNA helicase DDX31 & 2.07 \\
\hline Fads1 & Fatty acid desaturase 1 & 0.45 \\
\hline Nod3l & NOD3-like protein & 0.44 \\
\hline Bmp3 & Bone morphogenetic protein 3 & $0.43^{\mathrm{a}}$ \\
\hline$H t r 5 b$ & 5-hydroxytryptamine (serotonin) receptor 5B & 0.33 \\
\hline Gpr6 & G protein-coupled receptor 6 & $0.28^{\mathrm{a}}$ \\
\hline
\end{tabular}

${ }^{a}$ Verified by quantitative PCR analysis of independent neonatal rat islet samples 


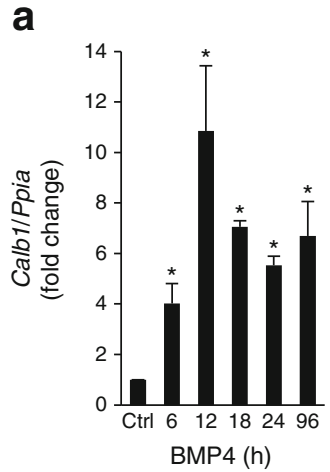

Fig. 3 BMP4 stimulates the expression of Calb1. Islets were stimulated with $50 \mathrm{ng} / \mathrm{ml}$ BMP4 for 0-96 h. (a) Relative Calb1 mRNA expression in neonatal rat islets was normalised to Ppia expression. (b) Protein expression in neonatal rat islets was determined by western blotting using primary antibodies against calbindin 1 and $\beta$-actin. A representative western

\section{Overexpression of Calb1 impairs GSIS}

To determine the role of calbindin1 in the BMP4-mediated effects on GSIS, we induced overexpression of Calb1 in dispersed neonatal rat islet cells. Overexpression of Calb1 significantly reduced GSIS (Fig. 4a). The transfection efficiency was more than $80 \%$, resulting in a robust upregulation of calbindin 1 protein (Fig. 4b). b

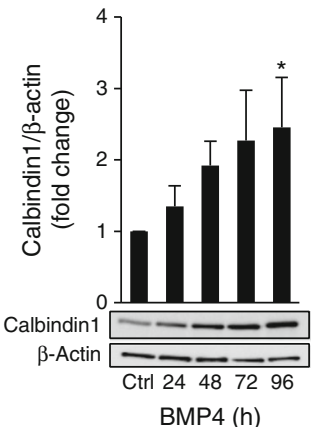

C

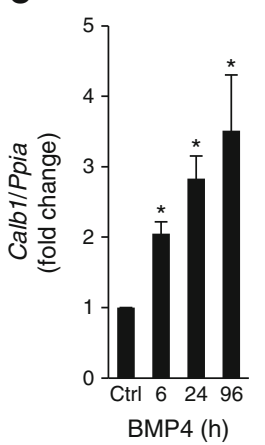

blot is shown and densitometry quantification of three blots was performed in ImageJ. (c) Isolated mouse islets were stimulated with $50 \mathrm{ng} / \mathrm{ml}$ BMP4 for 0-96 h. Relative Calb1 mRNA expression was normalised to Ppia expression. All data are mean $\pm \mathrm{SEM} ; n=3-4$

\section{BMP4 inhibition of GSIS and exocytosis is dependent on Calb1 upregulation}

We further investigated the effect of BMP4 on GSIS from pancreatic islets from Calb1 KO mice and WT littermates. As for neonatal rat islets, we observed a significant inhibition of GSIS by BMP4 treatment in WT adult mouse islets (Fig. 4c), but none in islets from Calb1 KO mice (Fig. 4c).
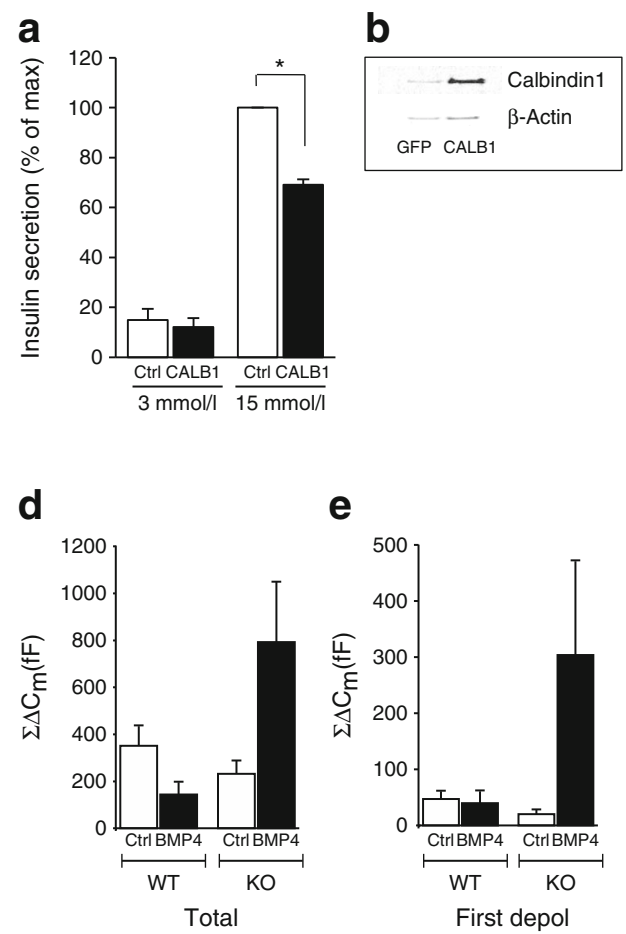

Fig. 4 Calbindin 1 expression affects islet glucose and BMP4 responsiveness. (a) GSIS from dispersed neonatal rat islet cells overexpressing calbindin1 or GFP. Insulin secretion is depicted as \% of control cells exposed to high glucose. (b) Western blot showing lentiviral overexpression of calbindin1. (c) Islets from Calb1 knockout (KO) mice and littermate WT controls were exposed to $50 \mathrm{ng} / \mathrm{ml} \mathrm{BMP} 4$ for $96 \mathrm{~h}$ and c

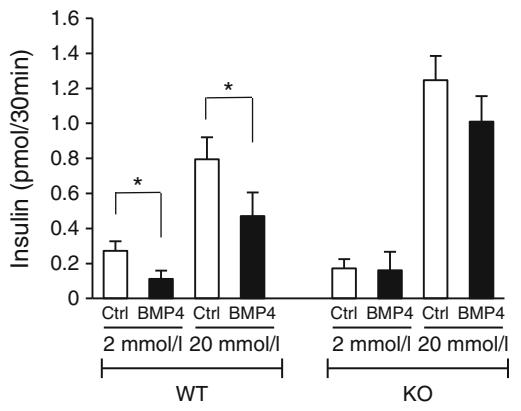

f

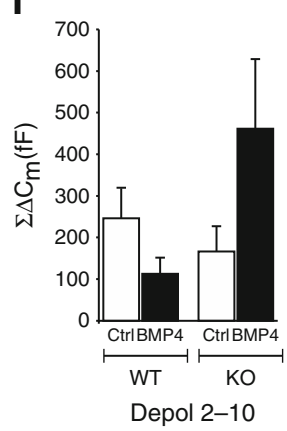

subsequently GSIS was determined, $n=3$. All data are mean \pm SEM. $(\mathbf{d}-\mathbf{f})$ Mean increase in membrane capacitance evoked by (d) the full train, (e) the first depolarisation and (f) depolarisation events 2-10 in single mouse beta cells isolated from Calb1 KO mice and littermate WT controls. CALB1, calbindin1; Ctrl, control; Depol, depolarisation; max, maximum. $p<0.05$ vs control 
In accordance with this, BMP4 did not reduce exocytosis in islets from Calb1 KO mice, but rather showed a nonsignificant increase in exocytosis (Fig. 4d-f).

\section{Discussion}

Here, we investigate the mechanism behind BMP4-mediated inhibition of GSIS in neonatal rat and adult mouse islets of Langerhans. This effect was not caused by reduced Ins 1 mRNA expression or protein content, or by changes in the number, size or localisation of insulin granules, but instead seems to be due to diminished $\mathrm{Ca}^{2+}$ influx through VDCCs resulting in reduced exocytosis. Metabolism of glucose increases intracellular ATP levels, resulting in closure of ATPdependent $\mathrm{K}^{+}$channels and membrane depolarisation. Subsequent opening of VDCCs triggers $\mathrm{Ca}^{2+}$ entry which induces insulin exocytosis (reviewed in [30, 31]). Hence, $\mathrm{Ca}^{2+}$ entry is essential for the amount of insulin released. We observed a BMP4-dependent decrease in the VDCC current, leading to a reduction in depolarisation-induced exocytosis and GSIS. The $\mathrm{Ca}^{2+}$ sensitivity of exocytosis was not decreased but was instead increased, indicating that the reduced $\mathrm{Ca}^{2+}$ current is the main determinant of reduced exocytosis. Reduced $\mathrm{Ca}^{2+}$ influx was also confirmed by a lack of response to $\mathrm{K}^{+}$in live cell $\mathrm{Ca}^{2+}$ measurements. Both observations are indicative of reduced depolarisation-evoked $\mathrm{Ca}^{2+}$ influx or increased $\mathrm{Ca}^{2+}$ buffering after BMP4 treatment. An increase in $\mathrm{Ca}^{2+}$ buffering would agree with the continued and more pronounced reduction in late exocytosis evoked by the latter depolarisations and the second train (Fig. 2d, e). Interestingly, our microarray analysis identified $\mathrm{Calbl}$, the gene encoding the $\mathrm{Ca}^{2+}$-binding protein calbindin 1 , as being upregulated by BMP4. We confirmed this regulation in independent rat islet samples and mouse islets. Although it has been suggested that neonatal and adult islets respond differently to glucose and other stimuli, BMP4 inhibited GSIS and upregulated calbindin 1 in both model systems. Overexpression of Calb1 reduced GSIS. The effect of BMP4 on GSIS was lost in islets from Calb1 KO mice (Fig. 4c). The exocytotic response to BMP4 in WT islets showed the same trend as previously observed (Figs 2a-e and $4 d)$, whereas this regulation was lost in islets from Calbl $\mathrm{KO}$ mice. There was a trend towards increased exocytosis in response to BMP4 in Calb1 KO mice, but this was nonsignificant and was not reflected in GSIS. BMP inhibition of GSIS was not observed in islets from Calb1 KO mice, suggesting that increased calbindin 1 expression may cause the observed BMP4-mediated decline in GSIS. Indeed, the BMP4-induced decrease in VDCC influx was remarkably similar to the effect observed upon overexpression of calbindin 1 in a pancreatic beta cell line (Fig. 2b-h and [29]). In addition to a $\mathrm{Ca}^{2+}$-scavenging effect, accumulating evidence suggests that calbindin 1 reduces $\mathrm{Ca}^{2+}$ currents via an association with L-type VDDCs
[29]. Glucose- and $\mathrm{Ca}^{2+}$-dependent translocation of calbindin 1 to the plasma membrane has previously been suggested to facilitate the interaction with L-type $\mathrm{Ca}^{2+}$ channels $[28,29]$. This could explain the lack of effect on the capacitance increase evoked by the first depolarisation (Figs $2 \mathrm{c}$ and $4 \mathrm{e}$ ), because the first influx of $\mathrm{Ca}^{2+}$ would induce translocation of calbindin 1 to the plasma membrane.

Glucose-induced $\mathrm{Ca}^{2+}$ oscillations occur in fewer BMP4treated islets compared with control cells, possibly because of reduced $\mathrm{Ca}^{2+}$ influx through VDCCs. This was further supported by the blunted $\mathrm{Ca}^{2+}$ response to high glucose and depolarising $\mathrm{K}^{+}$after BMP4 treatment (Fig. 3i-o and ESM Table 1). Loss of $\mathrm{K}^{+}$-induced $\mathrm{Ca}^{2+}$ influx was also observed in a calbindin1-overexpressing cell line, indicating that this effect is caused by increased calbindin 1 expression [27, 29]. Finally, $\mathrm{Ca}^{2+}$ oscillations persisted for longer in BMP4-treated islets when glucose was returned to $2.8 \mathrm{mmol} / \mathrm{l}$ (Fig. 2n and ESM Table 1), indicating a failure of the beta cells to repolarise to baseline. These data again suggest dysfunctional $\mathrm{Ca}^{2+}$ handling after BMP4 treatment.

Interestingly, calbindin 1 expression is increased in pancreatic islets from diabetic rats and mice $[32,33]$. Concomitant upregulation of BMP2 (but not BMP4) and calbindin1 in the islets of Langerhans has been observed in a type 2 diabetic mouse model [33]. BMP2 also upregulated the expression of calbindin1 and reduced GSIS in rat islets (data not shown). Generally, BMP2/4 may be considered as inflammatory markers in several metabolic tissues. Under diabetic conditions, expression of BMP2 or BMP4 has been reported to increase in the arteries, kidney, bones and islets [4, 14, 18, 19]. Increased BMP4 expression was reflected by increased circulating levels of BMP4 in type 2 diabetic patients in one study [13]. Thus, systemic inhibition of BMP2/4 appears to represent a possible strategy for broad targeting of a mediator of low-grade inflammation associated with type 2 diabetes. Interestingly, it was recently reported that systemic administration of the natural BMP inhibitor noggin lowered blood glucose levels in $d b / d b$ mice [14].

In conclusion, we have provided insight into the mechanisms involved in BMP4-mediated inhibition of insulin secretion and gene regulation in islets of Langerhans, and identified calbindin 1 as a mediator of BMP4-induced beta cell dysfunction.

Acknowledgements We acknowledge the technical assistance from $\mathrm{H}$. Fjordvang and L.G. Pedersen from the University of Copenhagen, S. Mach from the Ludwig Maximilian University of Munich, and B.-M. Nilsson and A.-M. Veljanovska-Ramsay from the Lund University Diabetes Center.

Funding We are thankful for support from the Novo Nordisk Foundation, Danish Research Council, Danish Diabetes Academy, European Foundation for the Study of Diabetes, A.P. Møller Foundation, Swedish Research Council, Region Skåne (ALF), Albert Påhlsson Foundation and Swedish Diabetes Foundation. LE is a senior researcher at the Swedish 
Research Council. GLC holds a postdoctoral grant from the Danish Diabetes Academy.

Duality of interest MLBJ, CB and KSF are employees of Novo Nordisk A/S

Contribution statement NB, GLC, MLBJ, CB and LE designed the study; GLC, MLBJ, AW, IGM, JF, KSF, MM, CB, NB and LE participated in acquisition, analysis and interpretation of data; GLC, NB and LE drafted the manuscript; and GLC, MLBJ, AW, IGM, JF, KSF, MM, CB, $\mathrm{NB}$ and LE revised the manuscript critically for important intellectual content and approved the final version to be published. NB is the guarantor of this work.

\section{References}

1. Weir GC, Bonner-Weir S (2004) Five stages of evolving beta-cell dysfunction during progression to diabetes. Diabetes 53(Suppl 3): S16-S21

2. Butler AE, Janson J, Bonner-Weir S, Ritzel R, Rizza RA, Butler PC (2003) Beta-cell deficit and increased beta-cell apoptosis in humans with type 2 diabetes. Diabetes 52:102-110

3. Rahier J, Guiot Y, Goebbels RM, Sempoux C, Henquin JC (2008) Pancreatic beta-cell mass in European subjects with type 2 diabetes. Diabetes Obes Metab 10(Suppl 4):32-42

4. Bruun C, Christensen GL, Jacobsen ML et al (2014) Inhibition of beta cell growth and function by bone morphogenetic proteins. Diabetologia 57:2546-2554

5. Sanvito F, Herrera PL, Huarte J et al (1994) TGF-beta 1 influences the relative development of the exocrine and endocrine pancreas in vitro. Development 120:3451-3462

6. Smart NG, Apelqvist AA, Gu X et al (2006) Conditional expression of Smad7 in pancreatic beta cells disrupts TGF-beta signaling and induces reversible diabetes mellitus. PLoS Biol 4:e39

7. Yamaoka T, Idehara C, Yano M et al (1998) Hypoplasia of pancreatic islets in transgenic mice expressing activin receptor mutants. $\mathrm{J}$ Clin Invest 102:294-301

8. Ahnfelt-Ronne J, Ravassard P, Pardanaud-Glavieux C, Scharfmann R, Serup P (2010) Mesenchymal bone morphogenetic protein signaling is required for normal pancreas development. Diabetes 59: 1948-1956

9. Kumar M, Jordan N, Melton D, Grapin-Botton A (2003) Signals from lateral plate mesoderm instruct endoderm toward a pancreatic fate. Dev Biol 259:109-122

10. Sui L, Geens M, Sermon K, Bouwens L, Mfopou JK (2013) Role of BMP signaling in pancreatic progenitor differentiation from human embryonic stem cells. Stem Cell Rev 9:569-577

11. Hogan BL (1996) Bone morphogenetic proteins in development. Curr Opin Genet Dev 6:432-438

12. Little SC, Mullins MC (2006) Extracellular modulation of BMP activity in patterning the dorsoventral axis. Birth Defects Res C Embryo Today Rev 78:224-242

13. Kim MK, Jang EH, Hong OK et al (2013) Changes in serum levels of bone morphogenic protein 4 and inflammatory cytokines after bariatric surgery in severely obese Korean patients with type 2 diabetes. Int J Endocrinol 2013:681205

14. Koga M, Engberding N, Dikalova AE et al (2013) The bone morphogenic protein inhibitor, noggin, reduces glycemia and vascular inflammation in $\mathrm{db} / \mathrm{db}$ mice. Am J Physiol Heart Circ Physiol 305: H747-H755
15. Bostrom KI, Jumabay M, Matveyenko A, Nicholas SB, Yao Y (2011) Activation of vascular bone morphogenetic protein signaling in diabetes mellitus. Circ Res 108:446-457

16. Goulley J, Dahl U, Baeza N, Mishina Y, Edlund H (2007) BMP4BMPR1A signaling in beta cells is required for and augments glucose-stimulated insulin secretion. Cell Metab 5:207-219

17. Akerfeldt MC, Laybutt DR (2011) Inhibition of Id1 augments insulin secretion and protects against high-fat diet-induced glucose intolerance. Diabetes 60:2506-2514

18. Tominaga $\mathrm{T}$, Abe $\mathrm{H}$, Ueda $\mathrm{O}$ et al (2011) Activation of bone morphogenetic protein 4 signaling leads to glomerulosclerosis that mimics diabetic nephropathy. J Biol Chem 286:20109-20116

19. Koga M, Yamauchi A, Kanaoka Y et al (2013) BMP4 is increased in the aortas of diabetic ApoE knockout mice and enhances uptake of oxidized low density lipoprotein into peritoneal macrophages. J Inflamm 10:32

20. Brunstedt J (1980) Rapid isolation of functionally intact pancreatic islets from mice and rats by percollTM gradient centrifugation. Diabete Metab 6:87-89

21. Eliasson L, Ma X, Renstrom E et al (2003) SUR1 regulates PKAindependent cAMP-induced granule priming in mouse pancreatic $\mathrm{B}$ cells. J Gen Physiol 121:181-197

22. Airaksinen MS, Eilers J, Garaschuk O, Thoenen H, Konnerth A, Meyer M (1997) Ataxia and altered dendritic calcium signaling in mice carrying a targeted null mutation of the calbindin D28k gene. Proc Natl Acad Sci U S A 94:1488-1493

23. Frobose H, Ronn SG, Heding PE et al (2006) Suppressor of cytokine Signaling-3 inhibits interleukin-1 signaling by targeting the TRAF-6/TAK1 complex. Mol Endocrinol 20:1587-1596

24. Gopel S, Kanno T, Barg S, Galvanovskis J, Rorsman P (1999) Voltage-gated and resting membrane currents recorded from $\mathrm{B}$ cells in intact mouse pancreatic islets. J Physiol 521(Pt 3):717-728

25. Gopel SO, Kanno T, Barg S, Weng XG, Gromada J, Rorsman P (2000) Regulation of glucagon release in mouse-cells by KATP channels and inactivation of TTX-sensitive $\mathrm{Na}+$ channels. J Physiol 528:509-520

26. Ammala C, Eliasson L, Bokvist K, Larsson O, Ashcroft FM, Rorsman P (1993) Exocytosis elicited by action potentials and voltage-clamp calcium currents in individual mouse pancreatic B cells. J Physiol 472:665-688

27. Sooy K, Schermerhorn T, Noda M et al (1999) Calbindin-D(28 k) controls $[\mathrm{Ca}(2+)](\mathrm{i})$ and insulin release. Evidence obtained from calbindin-d(28 k) knockout mice and beta cell lines. J Biol Chem 274:34343-34349

28. Parkash J, Chaudhry MA, Amer AS, Christakos S, Rhoten WB (2002) Intracellular calcium ion response to glucose in beta-cells of calbindin-D28k nullmutant mice and in betaHC13 cells overexpressing calbindin-D28k. Endocrine 18:221-229

29. Lee D, Obukhov AG, Shen Q et al (2006) Calbindin-D28k decreases L-type calcium channel activity and modulates intracellular calcium homeostasis in response to $\mathrm{K}+$ depolarization in a rat beta cell line RINr1046-38. Cell Calcium 39:475-485

30. Rorsman P, Braun M (2013) Regulation of insulin secretion in human pancreatic islets. Annu Rev Physiol 75:155-179

31. Eliasson L, Abdulkader F, Braun M, Galvanovskis J, Hoppa MB, Rorsman P (2008) Novel aspects of the molecular mechanisms controlling insulin secretion. J Physiol 586:3313-3324

32. Bazwinsky-Wutschke I, Wolgast S, Muhlbauer E, Peschke E (2010) Distribution patterns of calcium-binding proteins in pancreatic tissue of non-diabetic as well as type 2 diabetic rats and in rat insulinoma beta-cells (INS-1). Histochem Cell Biol 134:115-127

33. Keller MP, Choi Y, Wang P et al (2008) A gene expression network model of type 2 diabetes links cell cycle regulation in islets with diabetes susceptibility. Genome Res 18:706-716 